\title{
Commentary on the case study: Differences in socio- cognitive filters
}

\author{
Miroslava Szarkovà
}

The problem of socio-cognitive filters belongs to the highly topical themes of present social and work psychology with a straight outlook to the solution of basic economic questions. Mainly in the economic transformation process "which continues in Slovakia since 90's and creates the ground for the cooperation in economy between enterprises from different countries as well as for the originating of enterprises with concern abroad, which did not exist in our country till now" (Kita 1996:343) this problem gets new dimensions from two aspects:

It refers to the changing of property relationships, which influences the thinking, attitude and whole relationship to work of workers, not only employees, but also the management. It also refers to the change provoked by the implementation of new knowledge and experiences about enterprise management with respect to the orientation and position in the market, the view of personnel management and also the view of technological procedure.

Of course, the challenge of this procedure, which mainly progresses quickly, does not always lie in the acquisition of new knowledge but on the contrary causes a syndrom of information overload, not only for managers, who manage the transformation process of the enterprise, but also for employees, who attend it often passively and with fears. This problem can become manifest in insecurity, fear of the new and unknown. It is a reflection, as the author of the case study shows, with results in "two meanings". This is decribed as an organisational state in the enterprise, in which different interpretations or solutions of the current situation do not exist, and this forces managers to be busy with opportunities and threats, which is important in the process of decision-making (page 435). This moment by characterising differences in socio-cognitive filters I consider as decisive. It follows that in "90's the enterprises managing is in plenty of changes, which means that it is important to foresee and identify the change, overcome the resistance to the change, accept and adapt to the change" (Slavik 1996). This is at present in Slovak enterprises still multiplied by the complex changes being made in the relationships in macroeconomics, microeconomics and the social area, in which the enterprise

Miroslava Szarkovà, Faculty of Management, University of Economics Bratislava 
had it is performance, in which the enterprise could "live" and "survive", and which did arise before those managers from Slovak enterprises who ask for a quick orientation in new conditions and for an establishing of qualitatively other kinds of relationships mainly on the level of macroeconomics, as they were until then. This process was held and is held together by the reconstruction of relationships in the whole society /state, and therefore it is harder and more problematic, and for managers in enterprise often in first parts, it implies a trialand-error-procedure, because the theoretical and practical knowledge and experiences in this area were simply missing and also at present they are not overfilled.

The other, not less important problem is that there was a necessity to substitute the directive-authoritative managing and not suitable stereotypes by flexible managing methods, responsible for the exact methods of the transformation process in enterprise, where an application of know how tools and processes of "knowledge management" from abroad was often necessary.

An exact disharmony in this area often caused "two meanings" and "insecurity", which could become deeper in the differences in socio-cognitive filter in the exact association (Szarkova 1996).

As a thing which caused the "insecurity", there was also a certain lack of confidence regarding the progress of entrepreneurs and fear from exercising new methods and tools of managing mainly in the personnel, but also in other areas.

All of these problems were and until present are a content of the educational process in many Slovak enterprises. Results are mainly determined by using methods and processes, which respect the level of preparation and ability of Slovak managers to exercise in practice already known tools of managing and to realise the organisational changes in the way, like they are changing in time.

Only gradually, with aimed education, is it possible to overcome the differences in socio-cognitive filters, which "are for organisation a tool which gives the sense in certain situation".

Of course, the researches in this area (Szarkova 1993; 1995) show us many other problems, which are mentioned in this case study as well. There are facts confirmed and conclusions made from subject confrontation of perspectives of west "knowledge management" and methods in society Holderbank with problems of transformation, which the company Hirocem, and Slovak subsidiary of this company Holderbank does have.

\section{References}

Dusik, A. (1995): Utilization of normative methods by the creation of profesiograms in Hirocem, Diploma work. 
Kita, J. (1996): The cooperation of French and Slovak firms, Journal of economics.

Slávik, S. (1996): Specifics of management and process of success change, Collection: Transformation of enterprises in Slovakia - III, ES EU Bratislava.

Szarková, M. (1993): Exercising of normative methods by the choosing of managers, Collektion: Transformation of enterprises in Slovakia, ES EU Bratislava.

Szarková, M. (1995): Selection of employees as an assumption of the profit of enterprise, Collection: International Scientific conference: Economic and monetary transformation in central european countries, ES EU Bratislava.

Szarková, M. (1996): Change of attitudes of employees as a way out of the revitalization process in enterprise, Collection: Transformation of enterprises in Slovakia III, ES EU Bratislava.

Szarková, M. (1996): Managers' psychology, Kartprint Bratislava 1996. 